\title{
Relationship between BP (Baculovirus penaei) and energy reserves in larval and postlarval Pacific white shrimp Penaeus vannamei
}

\author{
Kenneth C. Stuck ${ }^{1,2}$, Lidia M. Stuck ${ }^{1}$, Robin M. Overstreet $^{1}$, Shiao Y. Wang ${ }^{3}$ \\ 'Gulf Coast Research Laboratory, PO Box 7000, Ocean Springs, Mississippi 39566-7000, USA \\ ${ }^{2}$ Department of Biology, University of Alabama at Birmingham, Birmingham, Alabama 35294, USA \\ ${ }^{3}$ Department of Biological Sciences, University of Southern Mississippi, Hattiesburg, Mississippi 39406-5018, USA
}

\begin{abstract}
The relationship between energy reserves of the penaeid shrimp Penaeus vannamei and Baculovirus penaei, or BP, were investigated in a series of experiments using mysis stage or early postlarval shrimp. Pre-exposure and post-exposure levels of protein and triacylgycerol (TAG) were determined. The effect of pre-exposure protein and TAG levels on susceptibility to BP infections was also investigated by starving a group of shrimp immediately prior to BP exposure. There was no consistent relationship between either pre-exposure or post-exposure protein levels and the percent of shrimp developing patent BP infections. There was, however, a significant positive correlation between TAG levels immediately prior to viral exposure and prevalence of infection $72 \mathrm{~h}$ later. Experimental reduction of TAG reserves prior to BP exposure delayed the development of a patent infection. In some, but not all, experiments there was a significant reduction in TAG levels of infected compared with uninfected shrimp $72 \mathrm{~h}$ post-exposure. The effect of patent BP infections on host TAG levels was subordinate to fluctuations in TAG content associated with the ontogeny of the hepatopancreas. Results of this study support histological observations that shrimp lipid levels can be altered by baculovirus infections Furthermore, high levels of energy reserves in the form of TAG are associated with increased susceptibility to BP infection in larval and postlarval shrimp.
\end{abstract}

KEY WORDS: Baculovirus - BP - Energy reserves - Penaeus vannamei Larval and postlarval shrimp

\section{INTRODUCTION}

Baculovirus penaei (Couch), commonly known as BP and designated by the International Committee on Taxonomy of Viruses (Francki et al. 1991) as PvSNPV, is one of approximately 18 viruses reported from penaeid shrimp (Overstreet 1994). Penaeus vannamei, the primary species of shrimp used for aquaculture in the Western Hemisphere, is susceptible to BP. In fact, BP can cause serious epizootics with high mortality of larval, and to a lesser extent, postlarval $P$. vannamei (see Overstreet et al. 1988). Typically, larval and young postlarval $P$. vannamei develop patent infections 18 to $24 \mathrm{~h}$ following initial exposure to BP (Stuck \& Overstreet 1994). Substantial mortalities or reductions in growth begin to occur 4 to $7 \mathrm{~d}$ post-exposure. That pat- tern of infectivity and pathogenicity is by no means invariable, and exceptions have been reported for experimental studies (LeBlanc \& Overstreet 1990, Overstreet 1994) and occur in commercial hatcheries (K.C.S. pers. obs.). Although variability in the apparent susceptibility of $P$. vannamei to BP may be related in part to the method used to detect the virus (Bruce et al. 1994), a variety of other factors undoubtedly are more significant. Overstreet (1994) has identified viral, host, and environmental factors that may influence BP infections. Among those factors is host nutritional condition.

The nutritional condition of an animal can be assessed biochemically in terms of available energy reserves. The principal energy storage materials in penaeid shrimp are lipids and protein (Schafer 1968, Barclay et al. 1983). Carbohydrates are considered to 
be a minor energy reserve in most decapod crustaceans (Barclay et al. 1983), including penaeid shrimp (Schafer 1968). Triacylgycerol (TAG) is the primary class of lipid used for energy storage in animals (Lehninger 1975). In penaeid shrimp, TAG reserves are rapidly depleted in response to nutritional stress (Chandumpai et al. 1991). However, during prolonged periods of starvation, protein serves as the major energy source in penaeid shrimp (Barclay et al. 1983). Stuck et al. (in press) reported that TAG reserves are significantly reduced in postlarval Penaeus vannamei during the first $24 \mathrm{~h}$ of starvation and are rapidly reestablished once feeding resumes. TAG content has been used extensively as an indicator of nutritional condition in larval crustaceans (Fraser 1989, Ouellet et al. 1992, Lovrich \& Ouellet 1994). Any type of stress that causes a significant reduction in feeding activities or absorption of nutrients will result in a rapid depletion of TAG reserves in crustacean larvae.

In this study we investigated the relationship between host energy reserves and susceptibility to BP infections. Our specific objectives were (1) to determine the effect that host nutritional condition immediately prior to BP exposure has on infectivity of the virus and (2) to determine the impact that patent BP infections have on energy reserves in larval and postlarval. Penaeus vannamei. We measured pre-infection and post-infection TAG and protein levels during a series of experimental BP exposures, some of which were originally designed to assess other aspects of the relationship between $B P$ infections and nutrition. The information obtained during this investigation contributes to a better understanding of how host factors can influence BP infections.

\section{MATERIALS AND METHODS}

BP infectivity experiments. The first phase of the study consisted of a series of 8 experiments in which groups of high health Penaeus vannamei (see Wyban et al. 1992) were experimentally infected with BP. Non-exposed controls were maintained through each experiment. The shrimp used in the experiments were obtained as either nauplii or postlarvae from one of several sources in the U.S.: (1) The Oceanic Institute, Waimanalo, HI, (2) Amorient Shrimp Farm, Kahuku, HI, (3) Harlingen Shrimp Farm, Los Fresnos, TX, and (4) Waddell Mariculture Center, Bluffton, SC. Regardless of the source, all shrimp used in these experiments originated from shrimp spawned from specific pathoqen free (SPF) broodstock produced from Kona Population 1 (see Wyban 1992). The source of shrimp, stage of development at which exposure to BP was initiated, and the approximate date and duration of each experiment are listed in Table 1. Shrimp used in Expts 1, 3, 4, and 5 were obtained as nauplii and reared to the desired age at $27 \pm 1^{\circ} \mathrm{C}$. The diatom Chaetoceros neogracile was fed to protozoeal stages 1 to 3 and brine shrimp nauplii to protozoeal stage 3 through postlarvae. Shrimp used in Expts 2, 6, 7, and 8 were obtained as postlarvae and maintained at $27 \pm$ $1^{\circ} \mathrm{C}$ on a diet of brine shrimp nauplii. Throughout each experiment, food was provided ad libitum. The C. neogracile used in all experiments was obtained initially from The Bigelow Laboratory for Ocean Sciences, West Boothbay Harbor, Maine (clone CCMP 1318) and reared on Fritz f/2 Algae Food ${ }^{(0)}$ (Fritz Chemical Company, Dallas, TX). Brine shrimp used in all experiments were obtained from Aquarium Products, Glen Burnie, MD (lot number 756). Water used in all the experiments, including the brine shrimp and diatom cultures, was produced from hw-Marinemix ${ }^{\otimes}$ (Hawaiian Marine Imports, Houston, TX) and deionized water. Disodium ethylenediaminetetraacetate (EDTA-Na ${ }_{2}$ ) was added to the salt water at a concentration of $10 \mathrm{ppm}$. Salinities were adjusted to $30 \mathrm{ppt}$ for larval stages and 25 ppt for postlarvae.

Immediately before exposure to $\mathrm{BP}$, a sub-sample of 15 to 20 shrimp from each experimental group was examined for the presence of BP polyhedra in the hepatopancreas (HP) following the diagnostic procedures for fresh shrimp described by Overstreet et al. (1988). The same diagnostic procedure was used to determine the prevalence of BP infections in all subsequent experiments. Lack of $B P$

apostlarvae were starved for $48 \mathrm{~h}$ immediately prior to viral exposure 
polyhedra in any of the pre-exposure stocks or in the unexposed controls confirmed the BP-free status of our experimental stocks. Expts 1, 2, 3, 4, and 7 were conducted in two $200 \mathrm{l}$ glass aquaria containing $150 \mathrm{l}$ salt water Expts 5,6, and 8 were each conducted in two 19 l aquaria containing 15 l of salt water Stocking densities were approximately 80 to $100 \mathrm{l}^{-1}$ for mysis shrimp, and 8 to $10 \mathrm{l}^{-1}$ for postlarvae. During each experiment, shrimp in one aquarium were exposed to $\mathrm{BP}$ and shrimp in the second aquarium from the pair served as the negative control. The strain of $B P$ and the procedures for viral administration have been described previously by Stuck \& Overstreet (1994).

In all experiments, 3 replicate samples consisting of approximately $30 \mathrm{mg}$ (wet weight) of larvae or postlarvae were collected for TAG analysis immediately prior to BP exposure. Protein samples were collected only during Expts 1, 2 and 7. If sufficient numbers of larvae or postlarvae remained, a second set of samples was collected for TAG and protein analysis $72 \mathrm{~h}$ after initial viral exposure. Samples for TAG and protein analysis were immediately frozen in liquid nitrogen and stored at $-70^{\circ} \mathrm{C}$. Beginning at 12 to $18 \mathrm{~h}$ postexposure and continuing through the duration of each experiment, the prevalence of infection was determined at periodic intervals by examining a subsample ( $\mathrm{n} \geq 10$ individuals depending on availability) of the BP-exposed and corresponding unexposed cultures. During 3 experiments (see Table 1), the effects of $\mathrm{BP}$ on energy reserves were monitored over extended periods of time. Through the duration of those experiments, replicate samples ( $n=3$ or 4 ) were periodically collected for protein and TAG analysis, and the prevalence of infection was determined from sub-samples $(n \geq 10$ ) of the BP-exposed and unexposed cultures. Data collected during Expts 1 to 8 were used to determine the relationship between preexposure energy reserves and susceptibility to BP infection. Data from Expts 1 to 4 and 7 were used to determine the impact that patent $\mathrm{BP}$ infections have on post-exposure energy reserves.

In the second phase of the study (Expt 9), we continued our investigation of the effect that pre-exposure host energy reserves have on susceptibility to infection by starving a group of postlarvae prior to BP exposure. The resulting pattern of infectivity was compared to a continually fed control group. Shrimp used in this study were obtained as nauplii from The Oceanic Institute and reared in a $95 \mathrm{l}$ aquarium to the postlarval stage (PL-16) following culture procedures described previously. Approximately 250 postlarvae from that common initial culture were placed into two 191 aquaria; one culture was maintained for $48 \mathrm{~h}$ without providing food and shrimp in the other were continually fed. Replicate samples $(n=3)$ were collected for
TAG and protein analysis from the common initial culture immediately prior to stocking the two $19 \mathrm{l}$ aquaria, and $48 \mathrm{~h}$ later from both the fed and starved groups of postlarvae. Fed and starved postlarvae were then exposed to BP at which time feeding of starved postlarvae resumed. Beginning at $18 \mathrm{~h}$ post-exposure and continuing for $192 \mathrm{~h}$, we periodically monitored the prevalence of infection from sub-samples $(n=15)$ of the starved-fed and fed cultures.

Protein and TAG determinations. Samples collected for protein and TAG analysis were homogenized in 20 volumes of cold distilled water using a small hand-held electric tissue grinder and then briefly sonicated. Two $50 \mu$ l aliquots of each sample were placed in pre-weighed, aluminum, micro weigh pans and dried at $80^{\circ} \mathrm{C}$ for $24 \mathrm{~h}$. After cooling to room temperature, each pan was reweighed to the nearest $0.1 \mu \mathrm{g}$ using a Cahn Electrobalance. The weights obtained were used to estimate the total dry weight of the aliquots taken for TAG and protein determinations.

A $25 \mu \mathrm{l}$ aliquot was used to determine the soluble protein content of each sample. Protein concentration was determined using a Bio-Rad protein assay kit based on the Bradford method (Bradford 1976). Bovine serum albumin was used as the standard.

Lipids extracted from $400 \mu \mathrm{l}$ aliquots were used to determine the TAG content of each sample (Bligh \& Dyer 1959). An internal standard, palmitic acid propyl ester, was added to the extracted lipids, and the samples were then evaporated to dryness by blowing a gentle stream of $\mathrm{N}_{2}$ gas over the samples. Neutral lipids were separated by thin layer chromatography on Type S-III chromarods using the solvent system dichloroethane:chloroform:acetic acid (926:31:1). The TAG content of each sample was quantified using an latroscan TH-10 Mark IV (see Ranny 1987). Tripalmitin was used as the standard. The concentrations of TAG and protein were calculated and expressed as $\mu \mathrm{g} \mathrm{mg}^{-1}$ dry weight.

Statistical analysis. Mean and standard error for TAG and protein concentrations were determined for each set of replicate samples collected at each sampling time. Differences in TAG and protein levels between BP-exposed and unexposed control shrimp were tested for significance using the Student $t$-test. Bonferroni-corrected $95 \%$ t-critical values were used when multiple comparisons were made

Analysis of differences in protein and TAG levels of infected and uninfected shrimp was limited to comparisons within individual experiments. Correlations between prevalence of infection and both protein and TAG concentrations were determined by simple linear regression. Analysis of variance was used to test for significance of the regressions. 
Table 2. Penaeus vannamei and Baculovirus penaei. Triacylglycerol (TAG) levels in larval and postlarval shrimp immediately prior to BP exposure and $72 \mathrm{~h}$ post-exposure during phase 1 of the study. TAG levels are expressed as mean $\mu \mathrm{g} \mathrm{mg}^{-1} \mathrm{dry}$ weight \pm standard error ( $n=3$ to 4). N: number of individuals examined for BP infections $72 \mathrm{~h}$ post-infection (\% infected). na: data not available. 'Significant difference $(p \leq 0.01)$ in $72 \mathrm{~h}$ post-exposure $T A G$ leveis between uninfected and infected shrimp

\begin{tabular}{|c|c|c|c|c|c|}
\hline \multirow[t]{2}{*}{ Expt } & \multirow[t]{2}{*}{ Pre-exposure } & \multicolumn{2}{|c|}{$72 \mathrm{~h}$ post-exposure } & \multirow[t]{2}{*}{$\mathrm{N}$} & \multirow[t]{2}{*}{$\%$ infected } \\
\hline & & Uninfected & Infected & & \\
\hline 1 & $1.8 \pm 0.3$ & $5.1 \pm 0.8$ & $4.8 \pm 0.6$ & 16 & 31 \\
\hline 2 & $1.2 \pm 0.1$ & $2.5 \pm 0.2$ & $1.8 \pm 0.3$ & 14 & 14 \\
\hline 3 & $3.7 \pm 0.6$ & $21.8 \pm 1.3$ & $4.6 \pm 1.4^{\circ}$ & 20 & 100 \\
\hline 4 & $8.4 \pm 0.6$ & $25.1 \pm 3.5$ & $14.4 \pm 1.7^{\circ}$ & 21 & 86 \\
\hline 5 & $12.0 \pm 5.1$ & na & na & 14 & 93 \\
\hline 6 & $1.3 \pm 0.2$ & na & na & 29 & 35 \\
\hline 7 & $6.7 \pm 1.4$ & $1.2 \pm 0.2$ & $1.3 \pm 0.5$ & 15 & 100 \\
\hline 8 & $3.5 \pm 0.3$ & na & na & 15 & 100 \\
\hline
\end{tabular}

\section{RESULTS}

\section{Establishment of patent BP infections}

In each of the 8 experiments conducted during the first phase of the study, viral polyhedra characteristic of a patent BP infection first appeared in the HP 18 to $24 \mathrm{~h}$ post-exposure. However, progression of the infection after the initial appearance of polyhedra was variable between different experiments (Table 2). During Expts $3,4,5,7$, and 8,86 to $100 \%$ of the shrimp exposed to BP were infected within $72 \mathrm{~h}$. In contrast, $35 \%$ or less of the BP-exposed shrimp in Expts 1,2 and 6 developed patent infections by $72 \mathrm{~h}$. In Expts 1 and 2, the prevalence of infection increased to $100 \%$ by 9 to $10 \mathrm{~d}$ after initial viral exposure. Substantial mortalities among BP-infected shrimp were evident only during Expts 1 and 3 , and occurred 4 to $7 \mathrm{~d}$ after initial viral exposure

\section{Effects of BP infection on shrimp energy reserves}

In the first phase of the study, TAG levels of BP. infected and uninfected shrimp $72 \mathrm{~h}$ post-exposure were determined during Expts 1 to 4 and 7 (Table 2). In Expts 3 and 4, the mean TAG levels of infected shrimp were reduced significantly $(\mathrm{p} \leq 0.01) \mathrm{com}$ pared to the uninfected controls. Mean TAG levels were reduced slightly, but not significantly in infected shrimp compared with uninfected animals during Expts 1 and 2. During Expt 7 , the mean TAG levels of infected and uninfected shrimp were both low and nearly identical. There was no significant correlation between mean $72 \mathrm{~h}$ post-exposure TAG levels of either infected or uninfected shrimp and prevalence of infection in the BP-exposed treatments due primarily to the low TAG levels observed during Expt 7
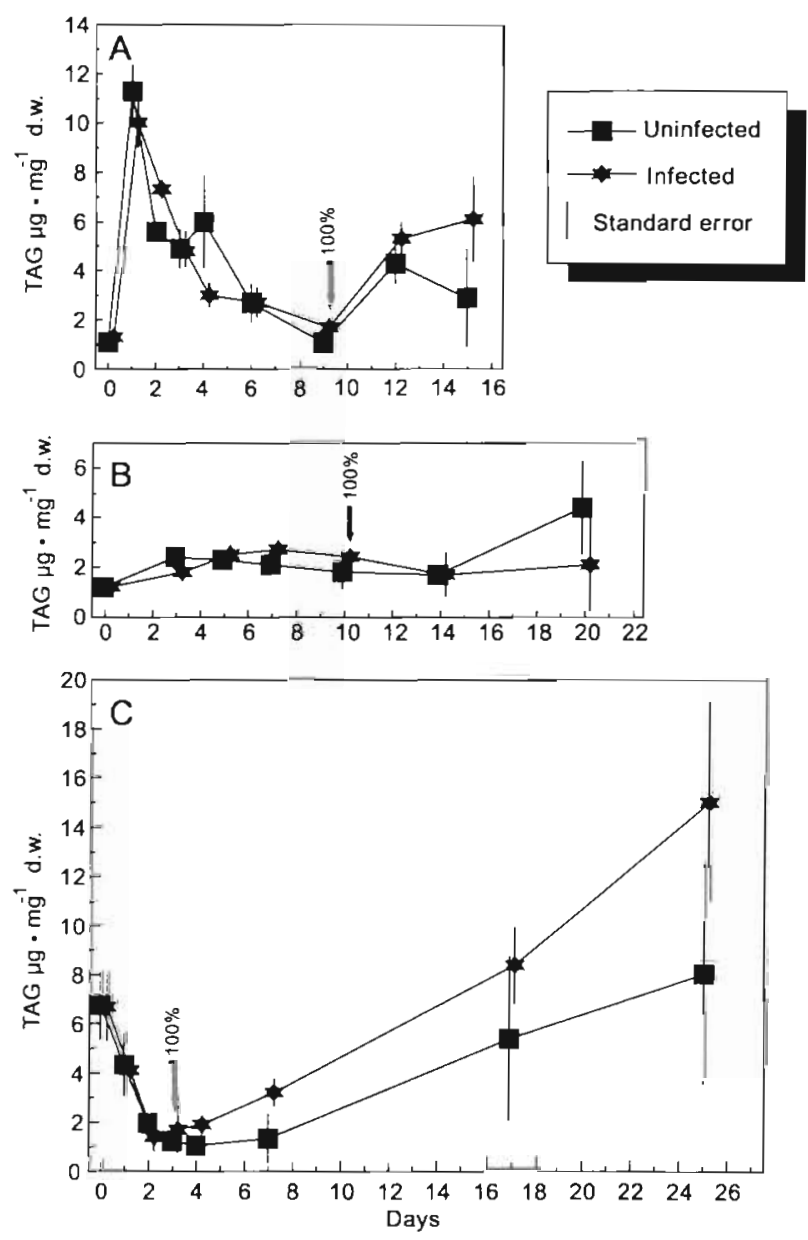

Fig. 1 Penaeus vannamei and Baculovirus penaei. Triacy]glycerol (TAG) levels of BP-infected and uninfected shrimp following initial exposure to BP. (A) Expt 1, initial exposure to $B P$ at $M$-I stage; (B) Expt 2, initial. exposure to BP at PL-9 stage; (C) Expt 7, initial exposure to BP at PL-9 stage. Values are expressed as means \pm standard error $(n=3$ or 4$)$. The sampling period at which $100 \%$ prevalence of infection among BP-exposed shrimp was obtained is indicated 
During Expts 1, 2, and 7, protein and TAG levels were monitored for extended periods ( 15 to 25 d) following initial exposure to BP. In all 3 experiments, TAG content of infected and uninfected shrimp followed similar patterns of change (Fig. 1). In Expts 1 and 7, TAG levels at the termination of the experiment were substantially, but not significantly higher in BP. exposed shrimp compared with unexposed shrimp, whereas in Expt 2, they were substantially lower. During all 3 experiments, differences in TAG levels observed between infected and uninfected shrimp were not significant based on Bonferroni $95 \%$ t-critical values. Among BP-exposed shrimp, there was no significant correlation between TAG levels and prevalence of infection. During Expts 1 and 2, protein levels
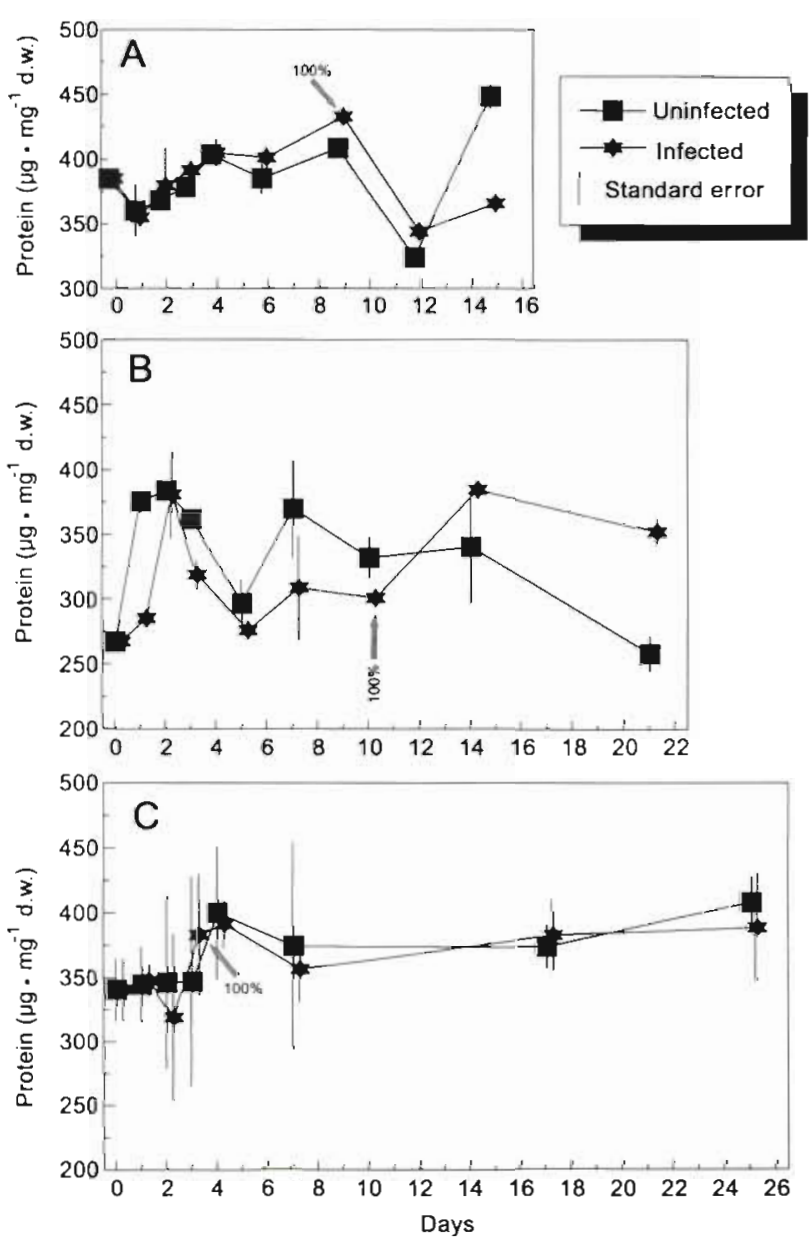

Fig. 2. Penaeus vannamei and Baculovirus penaei. Protein levels of BP-infected and uninfected shrimp following initial exposure to BP. (A) Expt 1, initial exposure to BP at M-I stage: (B) Expt 2, initial exposure to BP at PL-9 stage; (C) Expt 7, initial exposure to BP at PL-9 stage. Values are expressed as means $\pm \mathrm{SE}(\mathrm{n}=3$ to 4 ). The sampling period at which $100 \%$ prevalence of infection among BP-exposed shrimp was obtained is indicated
(Fig. 2) were variable between sampling periods in both BP-exposed and unexposed shrimp. Protein levels among infected shrimp at the end of Expt 1 were significantly lower $(p \leq 0.01)$ than uninfected shrimp, but were significantly higher $(p \leq 0.01)$ in infected compared to uninfected shrimp at the end of Expt 2. In Expt 7, protein levels of BP-exposed and unexposed shrimp remained relatively stable and were nearly identical throughout the course of the experiment. In all 3 experiments, protein levels were not significantly correlated with either prevalence of infection or TAG levels.

\section{Effect of pre-exposure energy reserves on infectivity of $B P$}

In all 8 experiments conducted during the first phase of the study, TAG levels were determined immediately prior to BP exposure (Table 2). Overall, there was a weak but significant positive correlation $\left(r^{2}=0.427, p \leq 0.05\right)$ between pre-exposure TAG levels and prevalence of infection $72 \mathrm{~h}$ post-exposure (Fig. 3). When mean pre-exposure TAG levels were $\leq 1.8 \mathrm{\mu g} \mathrm{mg}^{-1}$ the $72 \mathrm{~h}$ prevalence was $\leq 35 \%$. When mean pre-exposure TAG levels were $\geq 3.5 \mu \mathrm{g} \mathrm{mg}^{-1}$, the $72 \mathrm{~h}$ prevalence of infection was $\geq 86 \%$. Among those groups of shrimp with a mean pre-exposure TAG level $\leq 3.5 \mu \mathrm{g} \mathrm{mg}^{-1}$, there was a strong positive correlation. $\left(\mathrm{r}^{2}=0.959, \mathrm{p} \leq 0.001\right)$ between the preexposure TAG levels and $72 \mathrm{~h}$ prevalence of infection. Among those groups of shrimp with a mean pre-exposure TAG $\geq 3.5 \mu \mathrm{g} \mathrm{mg}^{-1}$, there was a weak but significant negative correlation $\left(\mathrm{r}^{2}=0.422, \mathrm{p} \leq 0.05\right)$ between pre-exposure TAG level and $72 \mathrm{~h}$ prevalence of infection. Pre-exposure protein levels, determined

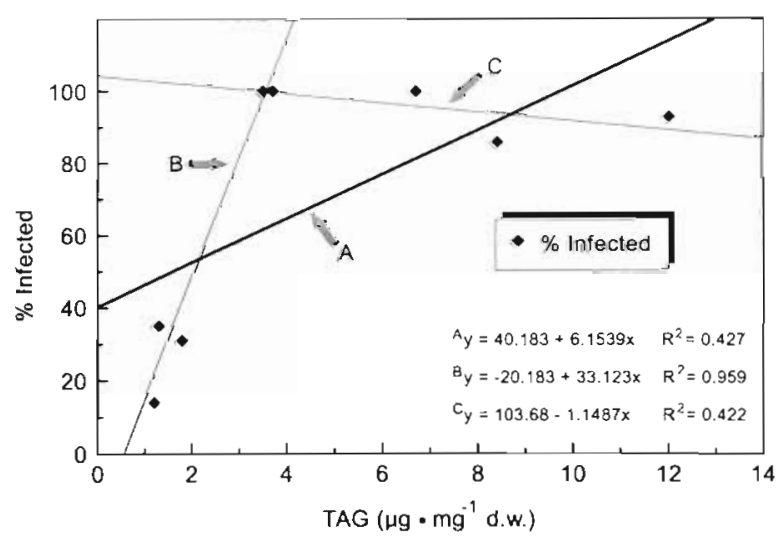

Fig. 3. Penaeus vannamei and Baculovirus penaei. Relationship between pre-exposure TAG levels and $72 \mathrm{~h}$ post-exposure prevalence of BP infection. The relationship is described by a simple linear regression model (heavy line) and a hyperbolic line fitted to the data points 


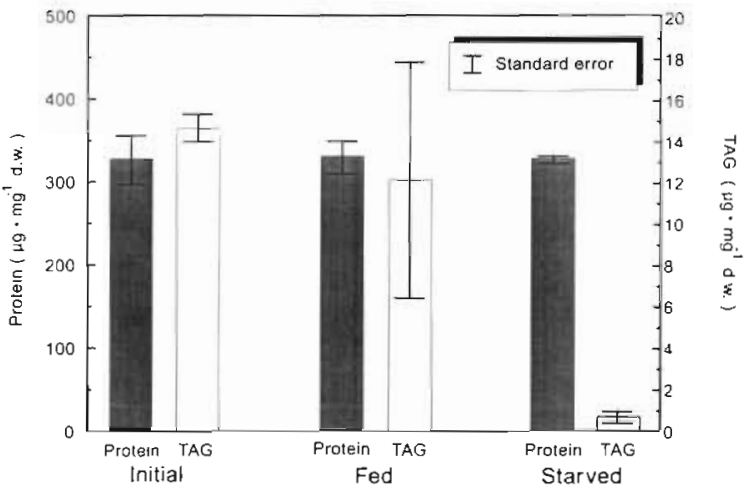

Fig. 4. Penaeus vannamei and Baculovirus penaei. Protein and TAG levels of fed and starved postlarvae prior to BP

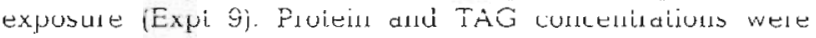
determined from the initial common stock, and 48 h later from the continually fed and starved groups of post-larvae. Values are expressed as means \pm SE $(n=3)$

during Expts 1,2, and 7, were not significantly correlated with $72 \mathrm{~h}$ prevalence of infection.

In the second phase of the study (Expt 9), we experimentally reduced energy reserves by starving shrimp immediately prior to BP exposure. TAG levels were reduced significantly $(p \leq 0.01)$ in postlarvae starved for $48 \mathrm{~h}$ compared to either the initial common stock of postlarvae or the continuously fed controls (Fig. 4). Protein levels were not influenced significantly by starvation. Among the fed controls, viral polyhedra were observed at $18 \mathrm{~h}$ post-exposure, and the maximum prevalence of infection (93\%) occurred at $72 \mathrm{~h}$ (Fig. 5). Viral polyhedra were first observed at $30 \mathrm{~h}$ post-exposure in the previously starved group of postlarvae: however, the prevalence of infection then increased rapidly to levels similar to fed postlarvae.

\section{DISCUSSION}

There appears to be a relationship between TAG content of penaeid shrimp and baculovirus infections in this and previous studies. Stuck \& Overstreet (1994) reported a reduction in the number and size of lipid droplets in the hepatopancreas (HP) of larval and postlarval Penaeus vannamei infected with BP. Vogt (1992) observed a proliferation of smooth endoplasmic reticulum (ER) into concentric membrane whorls indicative of lipid catabolism in HP cells of P. monodon infected with the baculovirus MBV He reported that HP cells in the advanced stages of infection lacked lipid reserves. Couch (1989) observed the formation of a membranous labyrinth (ML) from ER vesicles in BP-infected $P$. duorarum during the early stages of viral infection. He observed that the ML is closely associated with viral repli-

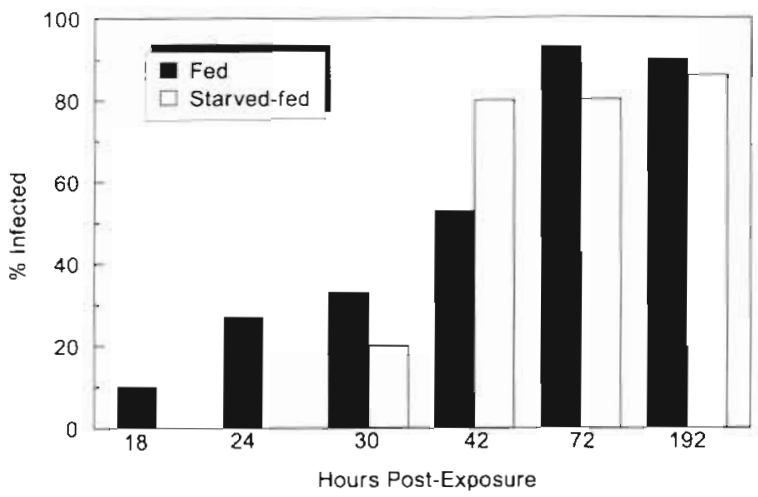

Fig. 5. Penaeus vannamei and Baculovirus penaei. Prevalence of BP infection in postlarvae starved $48 \mathrm{~h}$ prior to BP exposure compared to continually fed postlarvae (Expt 9). Values at expressed as tilie \% of pustiañat with viral pulyhedra of the total examined ( $n=15$ ) from each post-exposure sampling period. Feeding of starved postlarvae resumed after initial exposure to BP

cation, and one of its functional roles may be related to energy demand. TAG is the primary class of lipid used for energy storage in penaeid shrimp (Chandumpai et al. 1991) and constitutes approximately $18 \%$ of the total wet weight of HP in juvenile $P$. vannamei (K.C.S. unpubl. data). The reduction of lipids in response to baculovirus infection observed in previous studies is likely to be primarily attributable to TAG. In our study, we did not observe any significant or consistent relationship between protein levels and BP infections

Measurements of mortality due to viral exposure were not made in all 8 experiments conducted during the first phase of this study; however, data on the survival of BP-infected and uninfected control shrimp from Expts 1, 2, and 3 have been presented previously (Stuck \& Overstreet 1994). Although significant viral related mortality was observed during Expts 1 and 3, that mortality was not evident until 4 to $7 \mathrm{~d}$ post-exposure. In other experiments conducted during this study, substantial mortalities in either control or infected treatments were not evident during the first 72 h following initial viral exposure. It is therefore unlikely that the relationship between BP and TAG levels observed in this study is the result of differential survival of infected compared to uninfected shrimp.

Investigating the relationship between $B P$ and $T A G$ content is complicated by a variety of non-viral factors that can also influence TAG content. When interpreting results of this study, we must consider the possible effects of molting activities, stage of development, nutrition, and the inherent capacity of a brood of shrimp to store TAG.

Chandumpai et al. (1991) observed a relative increase in TAG content in the HP of sub-adult Penaeus esculentus during early premolt, but otherwise did not 
find a definite trend in TAG levels during the molting cycle. Samples collected for TAG analysis during our study consisted of approximately 10 (older postlarvae) to several hundred (mysis stage) shrimp. Since molting did not appear to be completely synchronous in our experimental cultures, the samples consisted of shrimp in a variety of molt stages, thus minimizing the possible effects of molting on TAG content.

The accumulation of TAG reserves in larval and postlarval Penaeus vannamei are significantly influenced by the stage of development. Since almost all the TAG in penaeid shrimp is found in the HP (Chandumpai et al. 1991), changes in the concentration of TAG relative to the total weight of the shrimp should parallel the ontogeny of that organ. In $P$. setiferus, there is no significant change in the volume of the HP from $\mathrm{M}$-II through PL-4, and the rate of increase in the HP volume does not equal that of the body until about PL-10 (Lovett \& Felder 1989). Thus, during that period of development the relative concentration of TAG should decrease. After PL-10, the HP begins to rapidly increase in size, and there should be a corresponding increase in the relative concentration of TAG. The pattern of change in TAG levels of both BP-exposed and unexposed shrimp observed during Expts 1, 2, and 7 (see Fig. 3) generally followed the ontogeny of the HP. The post-exposure effects of BP on TAG levels appear to be subordinate to those resulting from normal developmental patterns. Patent BP infections were associated with a 72 h post-exposure reduction of TAG levels in shrimp from some, but not all of the experiments conducted. Shastri-Bhalla \& Consigli (1994) reported a $29 \%$ reduction in TAG levels among insect larvae during the development of a patent baculovirus infection. Vogt (1992) suggested that the reduction of lipid reserves during the later phases of an MBV infection was due to energy requirements for viral replication. It is also possible that the reduction in energy reserves associated with patent baculovirus infections observed in this and previous studies resulted from reduced feeding activities of infected individuals. We also observed substantially higher TAG levels in infected compared with uninfected shrimp at the end of Expts 1 and 7 . Those results support the observations by Stuck \& Overstreet (1994) that after shrimp have recovered from the initial deleterious effects of BP, infected shrimp often experience accelerated growth.

Following initial viral exposure, all cultures were fed ad libitum, with brine shrimp from the same lot and therefore providing a similar nutritional diet. Differences in observed TAG levels between experiments attributable to nutrition should be minimal. However, during Expts 1 to 4 , when shrimp were transferred from a common stock to separate experimental aquaria, feeding levels were reduced 8 to $12 \mathrm{~h}$ prior to
BP exposure. That reduction in feeding may account in part for the relatively low pre-exposure TAG levels compared with the 72 h levels observed during those experiments. Despite those possible reductions in TAG, there was still a weak but significant correlation between pre-exposure TAG levels and $72 \mathrm{~h}$ prevalence of infection. However, because there is an upper limit $(100 \%)$ for prevalence of infection, the relationship between pre-exposure TAG levels and $72 \mathrm{~h}$ postexposure prevalence of infection (Fig. 3) was not linear over the entire range of TAG levels obtained during the study. There appears to be a 'threshold' concentration for TAG, beyond which larval and early postlarval shrimp are highly susceptible to BP infection.

In Expt 1 (Fig. 1A), pre-exposure TAG level was relatively low, but increased 10 -fold approximately $24 \mathrm{~h}$ after ad libitum feeding levels resumed. After $72 \mathrm{~h}$, the prevalence of infection suddenly increased from $31 \%$ ( $72 \mathrm{~h}$ post-exposure) to $80 \%$ (96 h post-exposure). We observed a similar response in Expt 9 conducted during the second phase of the study in which pre-exposure TAG levels were intentionally reduced by starving postlarvae for $48 \mathrm{~h}$ prior to $\mathrm{BP}$ exposure. In that experiment, there was a $12 \mathrm{~h}$ delay in the development of a patent infection among postlarvae with reduced TAG levels compared to that in the fed controls. In both of those experiments, the low pre-exposure TAG levels appear to have lengthened the prepatent period of the virus. Starvation and nutritional deficiencies also have been shown to delay or suppress development of baculoviruses in some insects (see Benz 1987).

The association we observed between pre-exposure TAG levels and the $72 \mathrm{~h}$ prevalence of infection appears to be related to the rate at which the virus multiplies after the shrimp is initially infected and not susceptibility to viral infection. Postlarval Penaeus vannamei that are in poor nutritional condition have slow growth rates and low TAG levels (Stuck et al. in press). Under such conditions, viral reproduction is likely to be slow and patent infections take longer to develop. As feeding levels increase and the nutritional condition of shrimp improves, viral replication reaches an optimal level. This would account for the strong positive correlation observed in this study between the $72 \mathrm{~h}$ prevalence of infection and groups of shrimp with pre-exposure TAG levels $\leq 3.5 \mu \mathrm{g} \mathrm{mg}^{-1}$. As TAG levels improve above optimal levels $\left(\geq 3.5 \mu \mathrm{g} \mathrm{\textrm {mg } ^ { - 1 }}\right.$ ) the immunocompetence of the shrimp may also improve, resulting in a decrease in patent infection rates. This would account for the negative correlation observed between the $72 \mathrm{~h}$ prevalence of infection and groups of shrimp with pre-exposure TAG levels $\geq 3.5 \mu \mathrm{g} \mathrm{mg}^{-1}$.

There also appears to be an inherent difference in the ability of various broods of shrimp, reared under similar ad libitum feeding conditions, to store TAG. For 
example, the maximum level of TAG recorded from Expt 1, in which mysis stage shrimp were used, was $11.4 \mu \mathrm{g} \mathrm{mg}^{-1} \mathrm{dry}$ wt. In comparison, TAG levels from mysis stage shrimp used in Expt 4 were as high as $25.1 \mu \mathrm{g} \mathrm{mg} \mathrm{mg}^{-1}$ dry wt. Postlarvae used in Expt 3 had TAG levels as high as $21.8 \mu \mathrm{g} \mathrm{mg}^{-1}$ dry wt compared to $12.0 \mu \mathrm{g} \mathrm{mg}^{-1}$ dry wt or less in other groups of postlarvae. Shrimp that have the capacity for storing large reserves of TAG, either immediately before or after exposure to BP, appear to be most susceptible to infection. That relationship does not necessarily serve as evidence for a direct interaction between baculovirus replication and lipid reserves as suggested by Vogt (1992), although such a relationship seems plausible. TAG levels may simply reflect the inherent metabolic activity of a group of shrimp. High TAG levels may be associated with fast growing shrimp in which the rapidly dividing tissues provide an excellent multiplication ground for the virus. Stuck \& Overstreet (1994) reported that BP was most pathogenic to fast growing shrimp, which are likely to have greater energy reserves than slow growing shrimp. The results of our study support that observation. Differences in susceptibility of various high health stocks to BP infection reported by Overstreet (1994) may be related to inherent differences in growth rates and ability to accumulate TAG reserves. In summary, a variety of factors may have an effect on host susceptibility to BP infections. Of those, TAG levels appear to have a significant influence. Future studies should investigate the relationship between pathogenicity of viral infections and energy reserves or growth rates in shrimp.

Acknowledgements. We thank Hugh Hammer, Heather Furst, and Mary Tussey of Gulf Coast Research Laboratory for assisting with technical aspects of the study, and Craig Browdy of Waddell Mariculture Center and James Sweeney of The Oceanic Institute for providing hatchery-reared shrimp. This study was conducted in cooperation with the U.S. Department of Agriculture, CSREES, Grant 92-38808-6920.

\section{LITERATURE CITED}

Barclay MC, Dall W, Smith DM (1983) Changes in lipid and protein during starvation and the moulting cycle in the tiger prawn, Penaeus esculentus (Haswell). J Exp Mar Biol Ecol 68:229-244

Benz G (1987) Environment. In: Fuxa JR, Tanada Y (eds) Epizootiology of insect diseases. John Wiley and Sons, Inc, New York. p 177-214

Bligh EG, Dyer W (1959) A rapid method of total lipid extraction and purification. Can J Biochem Physiol 37:911-917

Bradford MM (1976) A rapid and sensitive method for the quantitation of microgram quantities of protein utilizing the principle of protein dye binding. Analyt Biochem 72:248-254

Bruce LD, Lightner DV, Redman RM, Stuck KC (1994) Comparison of traditional and molecular detection methods for Baculovirus penaei infections in larval Penaeus vannamei. J Aquat Anim Health 6:355-359
Chandumpai A, Dall W, Smith DM (1991) Lipid-class composition of organs and tissues of the tiger prawn Penaeus esculentus during the moulting cycle and during starvation. Mar Biol 108:235-245

Couch JA (1989) The membranous labyrinth in baculovirusinfected crustacean cells: possible roles in viral reproduction. Dis Aquat Org 7:39-53

Francki RIB, Fauquet CM, Knudson DL, Brown F (eds) (1991) Classification and nomenclature of viruses. 5th report of the International Committee on Taxonomy of Viruses. Springer-Verlag, New York

Fraser AJ (1989) Triacylglycerol content as a condition index for fish, bivalve, and crustacean larvae. Can J Fish Aquat Sci $46: 1868-1873$

LeBlanc BC, Overstreet RM (1990) Prevalence of Baculovirus penaei in experimentally infected white shrimp (Penaeus vannamei) relative to age. Aquaculture 87:237-242

Lehninger AL (1975) Biochemistry, 2nd edn. Worth Publishers, Inc, New York

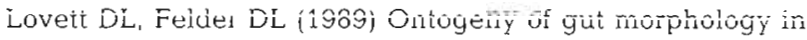
the white shrimp, Penaeus setiferus (Decapoda, Penaeidae). J Morphol 201:253-259

Lovrich GA, Ouellet P (1994) Patterns of growth and triacylglycerol content in snow crab Chionoecetes opilio (Brachyura: Majidae) zoeal stages reared in the laboratory. Mar Biol 120:585-591

Ouellet P, Taggart CT, Frank, KT (1992) Lipid condition and survival in shrimp (Pandalus borealis) larvae. Can J Fish Aquat Sci 49:368-378

Overstreet RM (1994) BP (Baculovirus penaei) in penaeid shrimps. USMSFP 10th Anniversary Review. Gulf Coast Research Laboratory Special Publication No. 1, Ocean Springs, MS, p 97-106

Overstreet RM, Stuck KC, Krol RA, Hawkins WE (1988) Experimental infections with Baculovirus penaei in the white shrimp, Penaeus vannamei (Crustacea: Decapoda), as a bioassay. J World Aquacult Soc 19:175-187

Ranny M (1987) Thin-layer chromatography with flame ionization detection. D. Reidel Publ, Dordrecht

Schafer HJ (1968) Storage materials utilized by starved pink shrimp, Penaeus duorarum Burkenroad. FAO Fish Rep 57(2):393-403

Shastri-Bhalla K, Consigli RA (1994) Lipid and fatty acid analysis of uninfected and granulosis virus-infected Plodia interpunctella larvae. J Invertebr Pathol 63:249-254

Stuck KC, Overstreet RM (1994) Effect of Baculovirus penaei on growth and survival of experimentally infected postlarvae of the Pacific white shrimp, Penaeus vannamei. J Invertebr Pathol 24:18-25

Stuck KC, Watts SA, Wang SY (in press). Biochemical responses during starvation and subsequent recovery in postlarvae of the Pacific white shrimp, Penaeus vannamei. Mar Biol

Vogt G (1992) Transformation of the anterior midgut and hepatopancreas cells by monodon baculovirus (MBV) in Penaeus monodon postlarvae. Aquaculture 107:239-248

Wyban JA (1992) Selective breeding of specific pathogen free (SPF) shrimp for high health and increased growth. In: Fulks W, Main KL (eds) Diseases of cultured shrimp in Asia and the United States. The Oceanic Institute, Honolulu, p 257-269

Wyban JA, Swingle JS, Sweeney JN, Pruder GD (1992) Development and commercial performance of high health shrimp using specific pathogen free (SPF) broodstock Penaeus vannamei. In: Wyban JA (ed) Proceedings of the Special Session on Shrimp Farming. World Aquaculture Society, Baton Rouge, p 254-260 